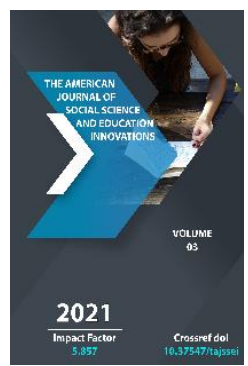

\title{
Comparative Analysis And Criteria For Highlighting The Circumstances Of The Course Of Action In Pashto And Russian
}

Eleonora Ilsurovna Zamaleeva

Researcher, Tashkent State University Of Oriental Studies, Tashkent, Uzbekistan

Journal Website:

http://usajournalshub.c

om/index,php/tajssei

Copyright: Original

content from this work

may be used under the

terms of the creative

commons attributes

4.0 licence.

\section{ABSTRACT}

The article is devoted to the comparative, as well as the criteria for highlighting the circumstance of the mode of action in the Pashto language, approaches to the selection of the circumstance of the mode of action among other grammatical categories in Pashto and Russian.

In terms of the functional features of adverbs, it is worth noting that an adverb always performs the function of a circumstance in a sentence. For example, the circumstances of time, place, degree, or mode of action in both Pashto and Russian.

In the adverbialization characteristic of the Pashto language adverbs, it can be noted that this paragraph considers the process of the transition of adverbs to other parts of speech.

In the Pashto language, as in the Russian language, the circumstance is divided into the following groups: place, time, degree, mode of action, and others.

\section{KEY WORDS}

Comparative analysis, circumstance of the course of action, aspect.

\section{INTRODUCTION}

1.1. Comparative analysis of the circumstances of the course of action in Pashto and Russian
1.2. Criteria for highlighting the circumstances of the course of action as a part of speech in Pashto and Russian 


\subsection{Comparative analysis of the circumstances of the course of action in Pashto and Russian}

It is well known that the circumstance of the mode of action in Pashto and Russian fulfills the function of a secondary member of the sentence, an explanatory word with the meaning of the action (state), which denotes the quality, the degree of manifestation, the way of performing the action, and answer the questions: how? how?

The purpose of this study is to highlight the history of the comparative study of the circumstances of the mode of action, as well as the adverbs expressed by the circumstances of the mode of action in the Pashto language and Russian.

Aspects of the study of the adverb in the function of the circumstances of the course of action.

Speaking about the study of adverbs in the function of the circumstances of the mode of action, the authors often emphasize the special role of the adverb in this regard, highlight various aspects in the study of this class of words, namely: historical, semantic-syntactic, functional, comparative and style-forming.

The semantic-syntactic approach is implemented in works (G. Sh Adzhimambetova and M. U Monraev).

So in the article by G. Sh. Adzhimambetova provides a semantic-syntactic classification of adverbs, which include adverbs of the image and mode of action, characterizing the manner, degree, intensity of action [1:65-68]. This also includes adverbs that reflect the qualitative aspect of a process or feature, regardless of which part of speech they are formed from. It is noted that in a sentence, adverbs can denote a variety of shades of action. At the same time, it should be noted the work of M.U. Monraev, where the dialects of the modern Kalmyk language are studied - one of the complex issues not only of Mongolian studies, but also of languages similar to system, this work describes all types of adverbs in a detailed structural and semantic analysis [8:137].

Article, D.S. Saiidyrakhimovoy, and D.M. Zhakypovoy, is devoted to the history of the study of adverbs in the Tajik language from the point of view of their formation and functioning, in particular in the role of circumstances of the mode of action [10:53-55]. Dissertation research, E.N. Gulidova, considers the issue of functional-communicative analysis of Russian adverbs on the basis of temporal and quantitative lexemes [4:277] This work is devoted to functional-communicative grammar (FCG), as well as the study of Russian adverbs in the linguodidactic aspect.

The comparative aspect in the study of the circumstances of the mode of action of adverbs was developed in the dissertation research, O. A. Glushchenko, this work is a fullscale multi-aspect description of the semantics of all adverbs of the mode of action in the literary language in comparison with one of the existing dialect systems (in the Arkhangelsk folk dialects.) [3:226]. It is also worth noting the following works (PhD and DSC) where a comparative analysis was considered on the example of different-structural languages such as (K.A. Rakhmatjonova - "Comparative typological study of grammatical categories of number and case in Hindi and Uzbek languages", Z.Ya. Sadikov - "Comparative analysis of the German and English translations of" Kutadgu Bilig "by Yusuf Has-Khadjib", N.A. Turapova - "Comparative analysis of somatic phraseological units of the Japanese and Uzbek languages (linguocultural aspect)."

The problems of comparative analysis in linguistics are presented in the dissertation research of W.K. Yusupov "Problems of comparative linguistics ", this dissertation research is a complete scientific work 
sufficiently developed in theoretical and practical terms.

As the above brief survey of works shows, at present, linguistics has accumulated a large amount of material on theoretical issues of comparative linguistics, but this material is still not sufficiently generalized and not brought together into a single whole. It can be noted that the methodology for comparing phonological (phonetic) systems of languages has been developed quite enough / see: Vasiliev 1969; Abduazizov 1974; Kaspransky 1976; Fedyanina 1979; and etc.

An important role in the development of the theory of comparative phonology was played by the system of phonological oppositions of N.S. Trubetskoy and the 12 binary distinctive oppositions established by R. Yakobson, G. M. Phant, M. Halle: I) vocal - non-vocal; 2) consonance - non-consonance; 3) discontinuity - continuity; 4) abruptiveness - nonabruptiveness; 5) brightness - dullness; 6) voicedness - deafness; 7) compactness diffuse; 8) low key - high key; 9) flat key - simple key; 10) sharp key - simple key; II) tension - nontension; 12) nasality - non-nasality / Jacobson et al. 1962 /. These distinctive features can serve as benchmarks when comparing phonemes of different languages.

The following basic principles of comparative linguistics for the study of languages for theoretical purposes were highlighted:

The principle of comparability; 2) consistency; 3) terminological adequacy; 4) sufficient depth of comparison; 5) taking into account the degree of kinship and typological proximity of the compared languages; 6) taking into account the positive and negative transfer of linguistic knowledge; 7) territorial nonlimitation; 8) accounting for functional styles; 9) two-sided comparison. c) the basic principles of the comparative study of languages for linguodidactic purposes, including all of the above principles, to which they also join the following: 10) the principle of synchronicity; li) simplicity; 12) minimal abstractness; 13) abbreviations; 14) registration of territorial dialects of the native language; 15) accounting for facilitation and interlingual interference.

The comparative aspect was also highlighted in the next work of the monograph by G.D.Basov, A.V. Kachur, A.V. Kihno, V.P. Musienko, N.G. Ozerov, G.P. Oleinik, N.P. Romanova , ES Snitko, OE Tvoronovich "Comparative grammar of the Russian and Ukrainian languages". The monograph presents a systematic description of the Russian and Ukrainian grammars at the derivational, morphological, syntactic levels in a comparative aspect, their common specific features, semantic originality, and grammatical means of each of the analyzed languages are noted. Along with this work, we can mention the work "Problems of the comparative grammar of Slavic languages", this work contains materials of the Soviet-Polish international conference "Synchronouscomparative study of the grammatical structure of Slavic languages" linguistic phenomenon is the work of V.B. Kashkin's "Comparative linguistics", as well as the textbook "Theory of translation and the comparative study of languages" by ES Vetrova.

The article, A. Stasenko, examines the parceling of circumstances in the modern Russian language (based on literary texts). In the scientific literature, parcels are a speech unit that is attached to the main part of the utterance during parcelling. In this work, the circumstance is a secondary member of the sentence, characterized by heterogeneity and diversity and is not a structurally strictly necessary part of the sentence [13:100-108]. According to the author, it is appears in a sentence only when the speaker wants to 
actualize, emphasize one or another aspect of the situation. The circumstances of the course of action characterize the way the action proceeds, called the predicate in the basic part of the sentence. Parcels of circumstances of the course of action can be expressed in adverbs.

In the article, T.P. Ivshina, investigates the functioning of the adverb in a publicistic text, its role in the implementation of the author's intention on the material of the memoirs and accusatory speeches of A.F. Horses. This work analyzes the peculiarities of an adverb as a feature word, its semantic enrichment in context, expressive possibilities, the adverb is also considered in rhetorical techniques, in particular in different types of repetition, and also analyzes its role in creating an emotionalevaluative field and significance for communicative success. Rhetorician [6:1-7].

\subsection{Criteria for highlighting the circumstances of the course of action as a part of speech in Pashto and Russian}

\section{Approaches to the study of adverbs as a function of the circumstances of the course of action in the Pashto language}

The functional aspect in the study of adverbs was developed in the works (K. A. Lebedev "The Grammar of the Pashto Language", A. L. Grunberg "Essay on the Grammar of the Afghan Language (Pashto)", ( يبنتوكر امريو هاند Sidikulo Rishtin Pashto The work of Anne Boyle David "Descriptive Grammar of Pashto and its Dialects", Herbert Penzl "A Grammar of Pashto A Descriptive Study of the Dialects of Kandahar Afghanistan", based on pashto material. actions.

So, K.A. Lebedev, gives a description of the adverb as an independent part of speech, which is distinguished in Pashto on the basis of syntactic function and meaning, also an adverb in a sentence is usually an adverbial word.
An adverb that refers to a verb expresses signs of an action or circumstances under which it occurs, as well as an adverb that defines an adjective or other adverb, indicates their signs. In Pashto, some adverbs can be used as postpositions [7:190-191].

This work also notes that the circumstance of the course of action can be expressed not only by adverbs, but also by the nouns with the infinitive of the verb with the preposition (ب) (pe) and the adverb (سره) - (sara) in the function of the postposition, by repeating the nouns with preposition (به) - (pe) and without it, noun with preposition (د) - (de) in combination (J لارى ) - (le lare) adjectives with (غوندى) - (gundi), repetition of adjectives, determinativeadverbial adverbial adverbial phrases (به بنـه جول) - (pe sha daul), as well as the circumstance of the course of action can be expressed by adjectives in adverbial function. He also noted that at the same time adjectives do not lose their features, but retains them. Therefore, their coordination takes place both in gender and in number [7:290-291].

The scientific approach to the study of adverbs, as well as the circumstances of the mode of action, was applied in his work by A.L. Grunberg, dedicated to the study of phonetics, morphology and syntax of the Afghan language (pashto). In this work, adverbs were investigated, as well as types of adverbs, and as members of a sentence, they can act in various texts.

In this work, A.L. Grunberg, explains that, like in many other Iranian languages, in the Afghan language there is no clear boundary between adverbs and nominal parts of speech adjectives and nouns. Nevertheless, he distinguishes a significant group of words that always or predominantly appear in the adverbial function and can be called adverbs proper. In this regard, A.L. Grunberg, distinguishes the functional and semantic feature of these adverbs proper, and divides 
them into the following groups: adverbs of place, time, measure and degree, interrogative adverbs, adverbs of the mode of action, while explaining that, according to the morphological structure, adverbs can be simple and complex, and also formed by the addition of words or stems [5:193].

In connection with the above, in a scientific study, A.L. Grunberg, distinguishes the adverbs of the mode of action, where a special group is made up of numerous borrowings from the Arabic language through dari, for example, adverbs ending in -ān, for example: tabānnaturally, mafassalān-in detail, qismatānpartially and others [5:196].

Anne Boyle David, in her work "Descriptive Grammar of Pashto and its Dialects, describes adverbs and types of adverbs, functions of adverbs in a sentence.

Along with these works, the work of the professor is also of great importance, (يبنتو كر امريو هاندصديقالله ربنتين) Sidikulo Rishtin "The grammar of the Pashto language", which describes in detail adverbs as an independent part speech, types of adverbs, functions of adverbs in a sentence.

\section{CONCLUSIONS}

In recent decades, the interest in comparative research has increased significantly in world linguistics. Despite this, comparative linguistics has not yet received full citizenship rights.

In order for comparative linguistics to take its rightful place among other branches of linguistics, it is necessary to further develop the theoretical foundations of this discipline (expansion and clearly substantiated formulation of the tasks of comparative linguistics, development of its principles, improvement of the comparative analysis methodology, selection of parameters for comparison).
Based on the achievements of typology and descriptive linguistics, comparative linguistics can currently solve a complex of theoretical and applied (linguodidactic) problems.

This article addresses the following range of issues:

1) The comparative nature of the circumstances of the mode of action of the Pashto and the Russian language is determined.

2) The comparative semantic and structural characteristics of the circumstances of the mode of action of the Pashto and the Russian language are distinguished.

3) Identifies the common components of the semantics of the circumstances of the mode of action on the example of literary discourse.

4) Reveals a kind of similarity in the circumstances of the mode of action when creating a newspaper discourse in Pashto and Russian.

\section{REFERENCES}

1. Adzhimambetova G.Sh. Lexico-semantic classification of adverbs in the Crimean Tatar language // Questions of spiritual culture - Philological sciences - 2011.-65-68

2. Boyle A.D Descriptive Grammar of Pashto and its Dialects- USA, 2014. P.500

3. Glushchenko OA Adverbs of the mode of action in the classification and comparative aspects Dis. for a job. uch.step. Candidate of Philological Sciences - PetropavlovskKamchatsky., 2006.-P.226

4. Gulidova E.N. Grammar of Russian dialects: linguodidactic aspect (based on work in a French-speaking audience) .Dis. for a job. uch.step. Candidate of Pedagogical Sciences - M., 2016. - P.277

5. Grunberg A.L. Essay on the grammar of the Afghan language (pashto) - Leningrad, 1987.- p. 237 p. 196 
6. Ivshina T.P. The rhetorical potential of an adverb in a publicistic text // Bulletin of the Leningrad State University. A.S. Pushkin.2010.-№ 5 C.1-

7. Lebedev K.A. Pashto grammar - M., 1970- p. 360, p. 292

8. Monraev M.U. "Adverbs in the modern Kalmyk language - Kalmyk ASSR: Elista, 1980 - p. 137

9. Rishtin S. Pashto grammar, بينتوكر امريو هاندصديقاله ربنتين زبارنسيدمحيالدين

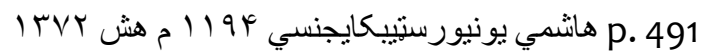

10. D.S. Saiidyrakhimova, D.M. Zhakypova, Adverb and its interpretation in tajik linguistics Adverb and its interpretation in Tajik linguistics // International Scientific Journal Theoretical and Applied Science.USA. 2018-No.05 (61) .P.53-55

11. D.S. Saiidyrakhimova, D.M. Zhakypova, Adverb and its interpretation in tajik linguistics Adverb and its interpretation in Tajik linguistics // International Scientific Journal Theoretical and Applied Science.USA. 2018-No.05 (61).P.53-55

12. Penzl H, Sloan I. "A Grammar of Pashto: $A$ Descriptive Study of the Dialect of Kandahar, Afghanistan" - Ishi Press, USA, 2009 P. 210

13. Arends A. Short syntax of modern Persian literary language. - M-L .: Iz-in ANSSSSR, 1941.

14. Akhmanova O, G.B. Mikaelyan. Modern syntactic theories. - $M$.: Publishing house of Moscow State University, 1963. - 155 p.

15. Akhmanova O.S. To the question of the difference between complex words and phraseological units (based on the material of English and Swedish) // Proceedings of the Institute of Linguistics of the Academy of Sciences of the USSR, Vol. IV. - M .: Ed. Academy of Sciences of the USSR, 1954. - B. 53-73.

16. Akhmanova O.S. Dictionary of linguistic terms. - M .: Soviet encyclopedia, 1966 .-$608 \mathrm{~b}$.
17. Hajiyeva N., Koklyanova A. Speech verbs in the Turkic languages // Historical development of the vocabulary of the Turkic languages. - M., 1961 .-- 323-460 p.

18. Goleva G.S. Farsi-Russian phraseological dictionary. - M .: Graal, 2000 .-- 626 b.

19. Gruzdeva S.I. Secondary members of the proposal at the present stage of their study // Russian language at school. - 1966. - No. 2. - p.95.

20. Zhirkov L.I. Persian language. (Elementary grammar). - M., 2009 .-- 208 p.

21. Iskhakova F.s. The main ways of word formation of Persian adjectives // Indian and Iranian philology (vocabulary issues). M. 1971. B. 3-14.

22. Kogan G.A. On the features of modeling idioms-adverbs in the Persian language // Studies in Iranian philology. - M., 2001, third edition. S. 25-37.

23. Kuchkartaev IK Valence analysis of speech verbs in the Uzbek language. - Tashkent: Fan, 1977.

24. Meshchaninov I.I. Sentence members and parts of speech. - M.-L., 1945.

25. Nikitin V.M. Morphology of the modern Russian language. Verb and adverb. Ryazan, $1961 .--123$ p.

26. Nikitin V.M. Circumstance as a minor member of a sentence in Russian as opposed to an addition. Scholarly notes. Volume XXVII. - Ryazan, 1961 .-- 141 p.

27. Nikitin V.M. The categories of circumstances in the modern Russian language. Special course manual. - Ryazan, 1973 -- $119 \mathrm{p}$.

28. Oranskiy I.M. Introduction to Iranian Philology. Ed. 2nd, supplemented. - $M$.: Nauka, 1988 .-- 390 p.

29. Peisikov L.S. Questions of the syntax of the Persian language. - M .: Ed. IMO, 1959 .-- 411 b.

30. Peisikov L.S. Essays on word formation of the Persian language. - M .: Ed. Moscow State University, 1973 -- $199 \mathrm{~b}$. 
31. Peisikov L.S. Lexicology of the modern Persian language. - $M$.: Ed. Moscow State University, 1975 -- 206 b.

32. Peshkovsky A.M. Russian syntax in scientific coverage. - M: Uchpedgiz; Questions about "questions". Selected Works. - M: Uchpedgiz, 1959.

33. Potebnya A.A. From notes on Russian grammar. - M., 1958.T.1-2.

34. Rastorgueva V.S. A brief outline of the grammar of the Persian language // Miller B.V. Persian-Russian dictionary. Ed. 2nd, rev. and add. - $M$.: Gosizdat foreign. and national dictionaries, - 1953 -- B. 613-668.

35. Rubinchik Yu.A. Fundamentals of the phraseology of the Persian language. - $M$.: Nauka, 1981 .-- 276 p. 